\title{
The Implementation of New Normal Online School in the Elementary School
}

\author{
Vevy Liansari ${ }^{1}$ \\ Universitas Muhammadiyah Sidoarjo, Jalan Mojopahit No.666 B, Sidowayah, Celep, Kec. Sidoarjo, Kabupaten \\ Sidoarjo, Jawa Timur 61215 \\ vevyliansari@umsida.ac.id
}

\begin{abstract}
The Corona Virus Diseases (Covid-19) pandemic happened in Indonesia since March 2020. It made all activities that gather large numbers of people to be avoided. Nowadays, the activities teaching and learning process change into online learning during the new normal period. The function of online learning in the new normal period is to connect educators and students through the internet network that could be accessed every time and everywhere. There are many kinds of online media when online learning such as the WhatsApp group, Google Classroom, Website, and other online media. The method used to collect sample data in the form of questions and answers to teachers and students of elementary school students regarding the results that have been felt during online school for elementary school students. The results of this study showed that the collaboration between teachers and students are very important. Thus, online schools can run based on their goals and expected outcomes.
\end{abstract}

Keywords: online school, new normal, elementary school.

\section{INTRODUCTION}

Online school is a crucial need in pandemic situation of Corona Virus Diseases 19 (Covid 19). Online media has penetrated into cultural practices related to social and political issues. Online school is a habit of learning activities followed by the process of reading, writing, which in the end what is done in the process of these activities can make a work [1]. Individual habits are not something natural from humans, but the process of achieving permanent results in the form of appreciating all the knowledge and skills obtained through education so that the individual concerned can do or do something that is beneficial to his life or the lives of others.

The implementation of online school is a habit of learning activities followed by the process of reading, writing by typing, and supported by a conducive environment [2]. It is not easy to get used to online school because it requires a strong commitment. This can be started with getting used to using gadgets, by creating a supportive environment. Online school can affect the level of success both at the educational level and also in community life [3]. In the view of Kellner and Share, online schools use the acquisition of skills and knowledge to read, interpret and compile exclusive types of texts and artifacts and to obtain intellectual tools and capacities so that they are able to fully participate in society and its culture [[4] Through strengthening online schools, the quality of education can be improved as a result of increasing the quality of human resources. Long life education can also be realized by strengthening online schools.

Educational institutions need to be a major concern for the government in this institutionalizing online school culture. Education as a means of shaping the future of a nation plays an important role in realizing a 
society with a literacy culture. Through education, we can transfer of values from the old generation to the new generation. The values of fond of reading and writing are appropriate and should be conveyed and implemented in education. Reading and writing skills are very important for a student. The ability to read is needed to enrich insight, vocabulary and points of view in understanding the situation. Meanwhile, writing skills are needed to express ideas and arguments. Education must be able to foster students' interest in reading and writing. The government through the Ministry of Education and Culture promotes a program of disseminating information technology education that involves Education and Technology. Based on Law of Minister Education Culture Number 23 in 2015 concerning the growth of character in children [5] to make students have the habit of reading and writing using online media technology, so that students become lifelong learners [6]. This activity will also have an impact on student learning outcomes. This movement does not only involve students, but rather a comprehensive effort that involves people at school even teachers, parents and society as a part of the educational ecosystem. However, practically not all policy makers understand correctly about the use of technology in home learning. Guidelines on the use of online school media technology have also been distributed to every school in Indonesia to be implemented, one of which is Elementary School.

At school, culture in the use of online media technology has been embedded in the curriculum used. Even though its implementation in schools as a place to seek knowledge is not yet fully implemented, it is optimal in fostering a culture of reading and writing or it is said that at least literacy culture has been instilled from an early age and its implementation can be measured. This online school in Elementary school program is realized so that students have the habit of using high online media, and are able to understand what they have read and be able to apply it in everyday life. From the result of interview with the Headmaster of Elementary School, "I have implemented the online school, but it is not maximal and the socialization is still ongoing". From the observations made by the researcher, it seems that every student has an interest in using online media in different ways, in the morning it appears that most students open WhatsApp class group when their teachers give topic materials in the morning. Even though, the teachers give materials from home by using online media that is sent in WhatsApp group class. The teachers have attended training in using online media before to develop materials to be given in online school. In addition, it is for supporting actualization of the online school program. The school gives questionnaire to the parents by using google form about consent for face-to-face learning once a week. After that, the school continued to carry out face-to-face schooling once a week with the parents' approval. Thus, the researcher wants to know the extent of the implementation of the online school in Zainuddin Waru, Sidoarjo, East Java.

\section{METHODS}

This study uses a qualitative research approach to the phenomenology type. The location of this research is SD Zainuddin Waru, Sidoarjo, East Java. The sampling technique used purposive sampling. The selected informants were those who understood correctly and were directly involved, and focused on elementary students. The subjects of this study were the principal, teachers, and 5 students of 30 students. Data collection techniques through observation, interviews, and documentation, to determine the validity of the data using a credibility test with triangulation techniques.

\section{RESERACH RESULTS AND DISCUSSION}

\subsection{Policy of the Implementation Online school in SD Zainuddin Waru, Sidoarjo, East Java}

SD Zainuddin Waru, Sidoarjo, East Java is one of the schools that implements an online school. Online school program based on regulation of the minister of education and culture on March, 2020 which is already running at the habituation, learning and development stages. From the results of the headmaster's interview, the implementation of the online school at this school began to be implemented in the 2020/2021 school year since the government launched the learn from home program to prevent the spread of the corona virus diseases (Covid-19). The main goal of online school that learns from home is to grow to stop the spread of Covid19 in school environment. In addition, creating an environment that complies with health protocols, namely wearing a mask, washing hands or using a hand sanitizer, checking body temperature, keeping a distance from one student sits in one bench, providing a place to wash hands and providing a hand sanitizer in every room. The efforts made by this school are to create a resilient environment against Covid-19. In addition, this school seeks to implement the regulations made by the Ministry of Education and Culture of the Republic of Indonesia regarding Decree Number 23 in 2015 concerning the growth of character in schools through habituation, one of which is through the compulsory reading holy Al-Qur'an lessons every day and others sources of the books [7]. The teachers remind the students by using WhatsApp group. After that collecting 
the assignment by using google classroom or private WhatsApp depends on the subject teacher.

\subsection{The Implementasi Online School in SD Zainuddin, Waru, Sidoarjo, East Java}

\subsubsection{Habitual Stage}

The online school of the habituation stage in SD Zainuddin, Waru, Sidoarjo, East Java has been carried out well, through this culture students become accustomed to reading the holy Al-Qur'an. The implementation of online school for elementary students is carried out every morning and every day. The implementation of reading activities 15 minutes before this lesson is in accordance with the regulations issued by the Minister of Education and Culture number 23 in 2015, the habituation program carried out by schools in addition to non-learning book literacy, also makes it a habit to read short letters in the Al-Qur'an, which aims to instill values -religious values so that students are always istiqomah in reading the Al-Qur'an. Schools do not only focus on academics, but also try to teach character education from an early age, one of which is to instill religious values. Literacy culture is also carried out by this school in Zainuddin Waru, Sidoarjo, East Java. This school is held every morning before lessons and takes place consistently.

In growing the habit of online school of elementary students in this school, namely learn from home. Not only students who were seen actively when online school, school principals and teachers also actively participated in implementing online schools. The online media used are varied, such as video, WhatsApp, google classroom, YouTube, and quizizz. Teachers must realize and support the importance of determining their own media used to reduce student confusion [4]. This school does not require using online media to do assignments or collect assignments. The teacher frees students to choose online media used in the current pandemic. There are no restrictions in implementing online media, if you have not completed the assignments, you can notify the class teacher first. From the results of student interviews, it was stated that online school has a positive impact on students, with the existence of an online school it can add new knowledge, get a lot of information, increase vocabulary, and be able to discuss materials of the subjects together with family. The results of this study are in line with research conducted by Tantri that the online school program supported by all school members is able to increase students' reading interest [8]. On Ningrum's research, which revealed that through reading activities students have extensive knowledge that creates curiosity or curiosity, students often ask questions when they do not understand something they read [9]. From the results of research at SD Zainuddin shows that implementing online school schools by providing opportunities to use time and maintain health, it will be easy to develop student potential.

\subsubsection{Learning stage}

The implementation of online school in learning at SD Zainuddin Waru, Sidoarjo, East Java has been implemented in every subject. The goal is to improve students' understanding of learning. Based on the researchers' observations, by making online school to Elementary school students a culture it was carried out by getting students used to implementing WhatsApp group classes. Each teacher's subjects use online media differently in learning from home. The online media used are video, WhatsApp, google classroom, YouTube, and quizizz. Online school in this learning creates an interesting and attractive atmosphere with various discussion activities about thematic books, supporting books from the library, and students' worksheets in the learning process.

Online school in this learning uses textbook reading sources such as thematic books, supporting books from libraries or students' worksheets. Each teacher has various others online media that are used as guidelines for deepening the material. They used their own ways based on training school that they got before. In addition, the reading sources used by students apart from thematic books, students use supporting books from libraries and students' worksheets. Teachers need to instill in students about response through the books and involvement of students in the learning [10]. As the results of interviews with school principals and class teachers who conducted learning through offline school once a week. The purpose of offline learning is so that students can add new knowledge that is not obtained through learning from home by using online school. In offline school, students meet the teachers and friends directly. They take feedback directly and teacher know students' abilities and performances. Education is able to bridge students to continue learning and working [11]. Using the right strategy will encourage students to have metacognitive abilities so that students can find the most appropriate learning strategy according to the content of the subject matter they read. Effective teachers are teachers who apply teaching techniques how students can read, write, and develop an understanding of their knowledge [12]. In implementing online school, the teacher should be able to give a positive and pleasant impression to the students [13]. 


\subsubsection{Development stage}

As for the online school in SD Zainuddin Waru, Sidoarjo, East Java, at the development stage, the focus of its activities is to improve student learning fluency and understanding. So that to measure students' understanding of learning using online media, it is done by writing activities. This can be seen when students during teaching and learning activities take place, students are asked to respond to books that have been read. The responses include writing stories in their own language on the students' note book. The reading strategy at the development stage is carried out by reading independently. The results of the activities to respond to the reading book include writing, pictures, and telling orally. Students also expressed their great pleasure and support regarding the provision of academic awards that are routinely given by teachers for student achievement and for appreciation of student literacy.

The success achieved in this school can be seen from the ability of students to understand the reading, namely students are able to write sentences that have been read. The activity of reviewing the readings is closely related to writing activities, so that it makes students better understand the reading in depth, hones their thinking skills and trains, the ability of students to make their own sentences. This literacy culture makes students to be independent, and have broad insight. This is a distinct advantage of this school.

Reading and writing activities are interrelated. So that, someone is able to write well, it should be started with reading activities first. Reading various types of books allows children to recognize various forms of writing that can stimulate children's writing skills [14]. The more children read, the better their writing skills will be encouraged. This is also in line with Saiful Azis' research which reveals that literacy has an influence on writing skills, acquisition of vocabulary has an impact on children's writing skills [15].

\section{CONCLUSION}

The online school in SD Zainuddin Waru, Sidoarjo, East Java is guided by a policy made by the government which is based on regulation of the minister of education and culture on March in 2020. The school's policy to build an online school is by improving facilities and infrastructure to support online school and offline school activities in new normal, such as creating an environment that complies with health protocols such as providing a place to wash hands and providing a hand sanitizer in every corner of the school, checking body temperature before entering the school area, requiring the use of masks and keeping a distance. The implementation of online school in SD Zainuddin Waru, Sidoarjo, East Java has carried out three stages, namely the habitual stage, learning stage, and development stage. The online school program requires good cooperation and support by all school residents and parents so that it increases student interest in learning and achievement.

\section{ACKNOWLEDGMENTS}

Thank you for Allah SWT, SD Zainuddin Waru, Sidoarjo, East Java best friends at Universitas Muhammadiyah Sidoarjo, parents, husband, best friends who support this article.

\section{REFERENCES}

[1] T. Y. Harjatanaya, G. Chysta, and S. Islamy, White Paper: Literasi di Indonesia. 2018.

[2] E. Rostiawati, "Membumikan Budaya Literasi di Kalangan Widyaiswara BPSDMD Provinsi Banten," J. Lingk. Widiyaswara, vol. 4, no. 1, pp. 1-6, 2017.

[3] I. M. N. Suragangga, "Mendidik Lewat Literasi Untuk Pendidikan Berkualitas," J. Penjaminan Mutu Lemb. Penjaminan Mutu Inst. Hindu Dharma Negeri Denpasar, vol. 3, no. 2, 2017.

[4] A. D. Kellner and J. Share, "Critical Media Literacy, Democracy, and the Reconstruction of Education," in Media Lit. A Read, D. M. S. R. Steinb, Ed. 2009, pp. 3-23,

[5] T. Y. Harjatanaya, G. Chysta, and S. Islamy, White Paper: Literasi di Indonesia. 2018.

[6] Kemendikbud, "Buku Gerakan Literasi Sekolah," in Direktorat Jendral Pendidik, Dasar dan Menengah, 2017.

[7] Kemendikbud, Peraturan Menteri Pendidikan dan Kebudayaan Republik Indonesia Nomor 23 Tahun 2015 Tentang Penumbuhan Budi Pekerti. 2019.

[8] A. A. S. Tantri and P. M. Dewantara, "Keefektifan Budaya Literasi Di SDN 3 Banjar Jawa Untuk Meningkatkan Minat Baca," J. Educ. Res. Eval, vol. 1.

[9] C. H. C. Ningrum, K. Fajriyah, and M. A. Budiman, "Pembentukan Karakter Rasa Ingin Tahu Melalui Kegiatan Literasi," Indones. Values Character Educ. J, vol. 2, no. 2, p. 69, 2019.

[10] D. Barlow, "Children's Literature in the Classroom: Engaging Lifelong Readers," Educ. Dig, vol. 77, no. 7, p. 71, 2012.

[11] I. F. R. Sari, "Konsep Dasar Gerakan Literasi Sekolah Pada Permendikbud Nomor 23 Tahun 2015 Tentang Penumbuhan Budi Pekerti," Al- 
Bidayah J. Pendidik. Dasar Islam, vol. 10, no. 1, pp. 89-100, 2018.

[12] M. Pressley, L. Mohan, L. M. Raphael, and L. Fingeret, "How does Bennett Woods Elementary School produce such high reading and writing achievement?," J. Educ. Psychol, vol. 99, no. 2, pp. 221-240, 2007.

[13] J. Bixler, S. Smith, and S. Henderson, "Inviting Teacher Candidates into Book Talks: Supporting a Culture of Lifelong Reading," Read. Horizons, vol. 52, no. 3, pp. 233-254, 2013.

[14] Latham, How Children Learn to Write: Supporting and Developing Children's Writing in Schools. 2012.

[15] S. Azis, "Implementasi Kultur Literasi Dalam Meningkatkan Kemampuan Membaca Menulis dan Berpikir Kritis Siswa SD Plus AlKausar Malang," in Univ, Islam Negeri Maulana Malik Ibrahim Malang, 2017. 